\title{
Comparison of Emotional Intelligence Levels and Problem Solving Skills of Prospective Teachers According to Different Variables
}

\author{
Mehmet Ali Akyol ${ }^{1}$ \& Elif Akdemir ${ }^{1, *}$ \\ ${ }^{1}$ Department of Curriculum and Instruction, Zonguldak Bülent Ecevit University, Zonguldak, Turkey \\ *Correspondence: Department of Curriculum and Instruction, Zonguldak Bülent Ecevit University, Zonguldak, \\ Turkey. Tel: 90-372-323-3870. E-mail: akdemirelif@gmail.com
}

Received: February 9, 2019

Accepted: June 6, 2019 Online Published: June 24, 2019

doi:10.5430/wje.v9n3p131

URL: https://doi.org/10.5430/wje.v9n3p131

\begin{abstract}
IQ is considered as a true criterion of intelligence while emotional intelligence is considered as a decisive in order to be happy and successful in life. It is of interest to the educational system that emotional intelligence can be developed at the same time. Emotional intelligence gained in the family will help to improve the school life, overcome the obstacles that people will encounter in their lives and solve the problems. In this study, emotional intelligence levels and problem solving skills of the prospective teachers were examined according to different variables. In this study, the cross sectional survey design was used to investigate the research questions with 1033 prospective teachers, 813 of whom were women and 220 were men, who agreed to participate in the study. The study group was chosen from the students of education faculty of the public university located near the black see region of Turkey. As a means of collecting data, the Bar-On Emotional Intelligence Scale, the Problem Solving Scale, and the Personal Information Form were used to obtain data from the participants. As a result of the study, the problem solving skills of prospective teachers don't differ according to gender and the class level; It was also found that emotional intelligence did not differ according to gender and the class level, but it had a significant difference according to age and department variables. In line with these results, in order to educate teachers with high level of emotional intelligence and problem solving skills, attention should be paid to the emotional characteristics of the teacher candidates. The change of emotional intelligence with different factors should be examined in follow up studies.
\end{abstract}

Keywords: emotional intelligence, problem solving skills, prospective teachers

\section{Introduction}

Having a high level of IQ as the most important condition of human life success has lost its importance in the 1990s with the emergence of the concept of emotional intelligence. People's ability to recognize, understand and manage their emotions are important to be happy and successful. However, one of the important points of education is that students can express themselves, manage their emotions and solve their problems correctly. At this point, the leadership of teachers is very important. It is thought that teachers who have high level of emotional intelligence and problem solving skills will make a significant contribution to gaining this behavior to their students. Based on this research, both emotional intelligence levels and problem solving skills of teacher candidates were examined based on different variables.

According to Özdemir (2015), it is easier for human beings to adapt to the environment by adding reason and willpower to being a social being. Together with cognitive intelligence, emotions have an important place in the process of adaptation and survival. Emotions have an important role in life interpretation and value-added, decision-making and implementation processes. It is based on the ability of one to realize his emotions, to direct his emotions, to understand other people's feelings, to transfer himself/herself to his/her emotions and to have social skills to express one's feelings in the right place and time (Cingisiz \& Murat, 2010). The important thing is not to have these emotions, but to control and control the emotional reactions that occur in the direction of these emotions, including emotional intelligence skills (Karaca, 2014). While the concept of emotional intelligence was first introduced to the work life, it became a center of interest for academics. The inclusion of the concept of emotional intelligence in the field of education has gained importance with the success of some individuals who have succeeded in academic 
achievement tests in real life (Durdu \& Şahin, 2017).

To date, many studies have been carried out in the field literature on emotion, emotional intelligence and problem solving. It can be said that the concept of emotion is both effective in directing human behaviors as well as in every aspect of social life and it has a significant share in the problems that may occur in interpersonal relations and solution of these problems (Güçlü, 2003). Bar-On (2005), in his study, found that older people had higher levels of emotional intelligence than young people, women were more successful in understanding feelings than men and men were more successful in controlling their feelings than women. In addition, Özmen (2008) reported that the emotional intelligence levels of primary school teachers did not differ according to the department and gender; as age and seniority increase, emotional intelligence has increased, meaning that emotional intelligence varies according to age and seniority.

Erdoğdu (2008) examined the relationship between emotional intelligence scores and some socio-demographic characteristics of university students. At the end of the study, it was observed that the emotional intelligence levels of the female students were significantly higher than the male students and the emotional intelligence levels of the outward-oriented students were higher than the inward-oriented ones. According to the democratic attitude of the mother and father and the departments they read, emotional intelligence was significantly differentiated and these variables supported the development of emotional intelligence. Babelan and Moenikia (2010) in their study showed that emotional intelligence and dimensions affect students' academic achievement statistically significantly. In another study, Pilis and Özbaş (2014) compared the emotional intelligence skills of the school administrators in terms of some variables according to their teachers' perceptions. As a result of the study, they stated that emotional intelligence did not change according to gender and changed according to teaching level. Durdu and Sahin (2017) examined the perceptions of the teachers working in the secondary school on their emotional intelligence in terms of some variables. According to the results of the study, the perception of emotional intelligence differed according to gender, age, duration of service and branches.

Emotional intelligence is considered to be an important factor in the fact that human being and others are aware of their feelings, being a healthy and happy individual in social life and finding a healthy way to solve problems. From this point of view, individuals with good emotional intelligence levels are expected to be able to communicate well with their surroundings, to fight without giving up in the face of problems and to find different and effective solutions. Emotional intelligence (EQ) can be taught and developed at all levels of life. In particular, the development of emotional intelligence increases the importance of education and training environments.

The process of developing problem solving skills requires different skills. The development of this skill is very important in the progress and comfort of humanity. Personal problem solving skills need to be developed. Because human beings have to act according to their own views in the face of difficulties (Akpinar, 2014). Problem solving can be explained as the process of reaching a solution by defeating the difficulties encountered in reaching a goal by using knowledge and adding creativity, originality or imagination (Güçlü, 2003). People with problem solving skills; innovative, responsible, flexible, courageous, adventurous, different thinker, self-confident, logical, objective, comfortable, emotional, energetic, effective, creative and producer has a structure. These characteristics are important for the success of one's life (Germi, 2006).

It is very important that teachers can solve the problems in the school environment. Teachers' perspective on problems, being able to replace oneself, to find fast and positive solutions to problems are very important in terms of society and family life. Teachers with these skills can provide a positive psychological environment. It is decisive that the person has the ability of problem solving in his struggle for life. Teachers who have high skill in contributing to problem solving skills contribute more. It can be said that the people who have this skill in the development of society will make a significant contribution. The fact that this can occur depends on the ability of individuals to fight effectively with the problems they face (Güçlü, 2003).

One of the biggest problems in schools is that children cannot solve the problem they are experiencing themselves or try. Even with the smallest problem, they are waiting for the support of the teacher for the solution and they are enjoying the solutions of the problems they face. Instead of solving the problems of children who will have to struggle on their own with many problems they will face in the future, it is very important to support them, motivate them and prepare them for life by teaching the stages of problem solving (Arkan, 2011). The aim of this study is to investigate the emotional intelligence levels and problem solving skills of pre-service teachers in terms of different variables.

According to Mayer and Salovey (1990), emotional intelligence is a sub-factor of social intelligence, which is associated with the ability of a person to be able to follow his/her own and others' feelings and feelings, to be able to distinguish between them and to be able to use the knowledge, behaviors and thoughts that s/he acquired in this process. Emotional intelligence can be described as the ability to manage emotions in a person's private life and in interpersonal 
relationships. Therefore, it is thought that individuals with advanced emotional intelligence can cope with obstacles and problems encountered in personal and social life and find different solutions and have more healthy and successful personal competences. One of the most important roles in the individual being an individual and coping with the environment is problem solving skills. Developing problem solving skills has a very important place in terms of human development and peacefulness (Güçlü, 2003). In all stages of education, the development of emotional intelligence and problem-solving skills is important in every period from kindergarten to higher education. For these reasons, this study will help teachers who have an important role in education process to transfer these skills to education process. Thus, it is thought that healthy and successful individuals will contribute to raising and solving social problems. The aim of this study is to determine whether teacher candidates' emotional intelligence levels and problem solving skills differ in terms of various variables and to support the results obtained with theoretical approaches. Do the emotional intelligence levels and problem solving skills of teacher candidates differ according to some variables? The question was investigated. The following sub-questions were formed to reveal the main question of the study.

1. Do students' problem-solving skills, emotional intelligence levels and sub-factors differ according to gender?

2. Do students' problem-solving skills and emotional intelligence vary according to age?

3. Do students' problem solving skills and emotional intelligence levels differ according to the department?

4. Do the problem solving skills and emotional intelligence levels of students differ according to grade level?

\section{Method}

In this study, a cross sectional survey design was used to investigate the research questions. The cross-sectional study is used to investigate the current attitudes, beliefs, opinions, or practices. (Creswell, 2002).

\subsection{Study Population}

The study was carried out with the participation of 1033 pre-service teachers studying in the education faculty of the state university in Black Sea region of Turkey during the 2017-2018 academic year. Demographic information of the study group are given in Table 1.

Table 1. Demographic Information

\begin{tabular}{llrr}
\hline Variables & Group & $\mathbf{n}$ & $\mathbf{\%}$ \\
\hline Gender & Female & 813 & 78,7 \\
& Male & 220 & 21,3 \\
& Total & 1033 & 100,0 \\
\hline Age & Group & $\mathbf{n}$ & $\mathbf{\%}$ \\
\hline & $17-20$ & 427 & 41,3 \\
& $21-24$ & 556 & 53,8 \\
& $25-28$ & 31 & 3,0 \\
& 29+ & 19 & 1,8 \\
& Total & 1033 & 100,0 \\
\hline Departments & Group & $\mathbf{n}$ & $\mathbf{\%}$ \\
\hline & Department of Primary Education & 223 & 22,6 \\
& Department of Preschool Education & 178 & 17,2 \\
& Department of Science Education & 88 & 8,5 \\
& Turkish Language Teaching Department & 159 & 15,4 \\
& Department of Social Studies Teaching & 97 & 9,4 \\
& Deprt. of Elementary Mathematics Education & 102 & 9,9 \\
& Psychological Counseling and Guidance Deprt. & 176 & 17 \\
& Total & 1033 & 100,0 \\
\hline Class & Group & $\mathbf{n}$ & $\mathbf{\%}$ \\
\hline & 1st grade & 295 & 28,6 \\
& 2nd grade & 257 & 24,9 \\
& 3rd grade & 255 & 24,7 \\
& 4th grade & 226 & 21,9 \\
& Total & 1033 & 100,0 \\
\hline & & &
\end{tabular}




\subsection{Data Collection Tools}

The data related to the study were obtained by means of the Bar-On Emotional Intelligence Scale. A personal information form was used to determine the gender, age, department and class level of the students. In order to determine the levels of emotional intelligence, Bar-On Emotional Intelligence Scale developed by Reuven Bar-On in 1997 and adapted to Turkish by Acar (2001) was used. The scale consists of five dimensions. These dimensions; personal skills, interpersonal skills, compliance, coping with stress and general mood. Cronbach Alpha coefficient of the whole scale was found to be 0.92 . Problem Solving skills were determined by the problem solving scale developed by Güler (2006). In order to determine the reliability of the scale, Cronbach Alpha coefficient was examined and found to be 0.90 .

\subsection{Data Analysis}

Data were analyzed using the SPSS for Windows 20.0 program. When Table 2 is examined, according to Kolmogorov-Smirnov normality test, the data of all scale scores and sub-factors did not show normal distribution ( $p$ $<0.05$ ). According to this, non-parametric tests were used in the analysis. Descriptive statistical methods (frequency, percentage, mean, standard deviation) were used to evaluate the data. The Mann-Whitney U test was used to compare the quantitative data and Kruskal Wallis $\mathrm{H}$ test was used to compare the parameters between groups.

Table 2. Normality Test

\begin{tabular}{lccc}
\hline \multicolumn{4}{c}{ Kolmogorov-Smirnov } \\
\hline & Statistic & Df & Sig. \\
\hline Problem Solving Scale &, 042 & 1033 & 0,000 \\
Emotional intelligence &, 029 & 1033 & 0,034 \\
1-Personal Skills &, 039 & 1033 & 0,001 \\
2-Interpersonal &, 070 & 1033 & 0,000 \\
3-Compliant &, 043 & 1033 & 0,000 \\
4-Coping with Stress &, 055 & 1033 & 0,000 \\
5-General Mood Status & 0,65 & 1033 & 0,000 \\
\hline
\end{tabular}

\section{Findings and Discussion}

3.1 Comparing Problem Solving Skills, Its Sub-Factors and Emotional Intelligence Levels According To Gender Variable

In the first research question whether the problem solving skills, emotional intelligence and its sub-factors change based on the gender is investigated.

Table 3. Comparison of the Factors and Sub-Factors by the Gender

\begin{tabular}{|c|c|c|c|c|c|c|}
\hline Factors and sub-factors & Gender & $\mathbf{n}$ & Mean Rank & SD & $\mathbf{U}$ & p \\
\hline \multirow[t]{2}{*}{ Problem Solving Skills } & Female & 813 & 516,70 & 1 & 89185,5 & 0,95 \\
\hline & Male & 220 & 518,11 & & & \\
\hline \multirow[t]{2}{*}{ Emotional Intelligence } & Female & 813 & 519,02 & 1 & 87785,0 & 0,675 \\
\hline & Male & 220 & 509,52 & & & \\
\hline \multirow[t]{2}{*}{ Personal Skills } & Female & 813 & 520,72 & 1 & 86409,0 & 0,441 \\
\hline & Male & 220 & 503,27 & & & \\
\hline \multirow[t]{2}{*}{ Interpersonal relationships } & Female & 813 & 541,19 & 1 & 69765,0 & $0,0^{*}$ \\
\hline & Male & 220 & 427,61 & & & \\
\hline \multirow[t]{2}{*}{ Compliant } & Female & 813 & 513,63 & 1 & 86687,5 & 0,484 \\
\hline & Male & 220 & 529,47 & & & \\
\hline \multirow[t]{2}{*}{ Coping with Stress } & Female & 813 & 498,81 & 1 & 86687,5 & $0,0^{*}$ \\
\hline & Male & 220 & 584,23 & & & \\
\hline \multirow[t]{2}{*}{ General Mood Status } & Female & 813 & 522,31 & 1 & 85111,5 & 0,271 \\
\hline & Male & 220 & 497,37 & & & \\
\hline
\end{tabular}

When the results of Table 3 are examined, the difference between the arithmetic means of the male and female students was not statistically significant. According to the findings, it can be said that the problem solving skills did not change 
according to gender $(U=89185,5, p>0,05)$. When the results of Table 3 are examined, the difference between the arithmetic mean of female and male students was not statistically significant. According to the findings, it can be said that emotional intelligence skills do not change according to gender $(U=87785,0, p>0.05)$.

\subsection{Comparing Problem Solving Skills and Emotional Intelligence Levels According to Age Variable}

In the second research question, whether the problem solving skills and emotional intelligence change based on the age variables is investigated.

Table 4. Comparison of the Factors by the Age Variable

\begin{tabular}{|c|c|c|c|c|c|c|c|}
\hline Factors & Age & $\mathbf{n}$ & $\overline{\mathbf{X}}$ & SD & $\mathrm{X}^{2}$ & $\mathbf{p}$ & Fark Puanları \\
\hline Problem & $17-20(\mathrm{~A})$ & 427 & 478,29 & 1 & 26,059 & 0,0 & B-A \\
\hline \multirow[t]{3}{*}{ Solving Skills } & $21-24$ (B) & 556 & 531,88 & & & & C-A \\
\hline & $25-28(\mathrm{C})$ & 31 & 633,71 & & & & D-A \\
\hline & $29+\quad(D)$ & 19 & 761,16 & & & & D-B \\
\hline Emotional & $17-20(\mathrm{~A})$ & 427 & 493,76 & 3 & 15,795 & 0,001 & D-A \\
\hline \multirow[t]{3}{*}{ Intelligence } & $21-24$ (B) & 556 & 524,52 & & & & D-B \\
\hline & $25-28(\mathrm{C})$ & 31 & 554,98 & & & & D-C \\
\hline & $29+\quad(D)$ & 19 & 757,50 & & & & \\
\hline
\end{tabular}

Table 4 shows that; According to the results of the Kruskal-wallis H Test conducted in order to determine whether the problem solving skill scores of the students participating in the study showed a significant difference according to the age variable; problem solving skills vary according to age $\left(X^{2}=26,059, p<0,05\right)$. Accordingly, the problem solving skills of 17-20 year old students are lower than the other age groups. In addition, the problem solving skills of 29 years old and 21-24 years old students are compared; A statistically significant difference was found in favor of over 29 years. When the Table 4 is examined; According to the results of the Kruskal-wallis H Test conducted to determine whether the emotional intelligence level scores of the students participating in the study showed a significant difference according to the age variable; emotional intelligence levels differ according to age $\left(X^{2}=15,795, p<0,05\right)$. According to this, the emotional intelligence level of the 29+ group students is higher than the other age group students.

\subsection{Comparing Problem Solving Skills and Emotional Intelligence Levels According To Department Variable}

In the third research question, whether the problem solving skills and emotional intelligence change based on the department is investigated.

Table 5. Comparison of the Factors by the Department Variable

\begin{tabular}{|c|c|c|c|c|c|c|c|}
\hline Factors & Department & $\mathbf{n}$ & $\overline{\mathbf{X}}$ & SD & $\mathrm{X}^{2}$ & $\mathbf{p}$ & Difference \\
\hline Problem & (1) Primary School & 233 & 524,83 & \multirow[t]{7}{*}{6} & \multirow[t]{7}{*}{37,990} & \multirow[t]{7}{*}{0,00} & $1-7$ \\
\hline \multirow[t]{6}{*}{ Solving } & (2) Preschool & 178 & 602,29 & & & & $2-1,2-4,2-5$, \\
\hline & (3) Science & 88 & 593,70 & & & & $2-6,2-7$ \\
\hline & (4) Turkish Language & 159 & 488,45 & & & & $3-4,3-6,3-7$ \\
\hline & (5) Social Studies & 97 & 523,02 & & & & \multirow[t]{3}{*}{$5-7$} \\
\hline & (6) Mathematics Teaching & 102 & 453,13 & & & & \\
\hline & (7) Guidance and Psyc. Coun & 76 & 441,51 & & & & \\
\hline Emotional & (1) Primary School & 233 & 524,11 & 6 & 20,027 & 0,003 & $2-1,2-4,2-5$, \\
\hline \multirow[t]{6}{*}{ Intelligence } & (2) Preschool & 178 & 595,85 & & & & \multirow[t]{6}{*}{$2-6,2-7$} \\
\hline & (3) Science & 88 & 533,82 & & & & \\
\hline & (4) Turkish Language & 159 & 494,64 & & & & \\
\hline & (5) Social Studies & 97 & 485,74 & & & & \\
\hline & (6) Mathematics Teaching & 102 & 459,36 & & & & \\
\hline & (7) Guidance and Psyc. Coun & 76 & 490,26 & & & & \\
\hline
\end{tabular}

Table 5 shows that; According to the results of Kruskal-wallis H Test conducted to determine whether the problem solving skill scores of the students participating in the research showed a significant difference according to the department variable; problem solving skills vary according to the department $\left(X^{2}=37.990, p<0.05\right)$. The problem 
solving skills of primary school students are higher than the students of psychological counseling and guidance department. Again, the problem solving skills of Preschool Teaching department students are raised more than the students of Science Education Department. Moreover, the problem solving skills of Science Education department students are higher than Turkish Language, Mathematics Teaching departments and Guidance and Psychological Counselling department students. Finally, the problem solving skills of the students of Social Studies Education Department are higher than the students of Guidance and Psychological Counselling department.

Table 5 shows that according to the results of the Kruskal-wallis H Test conducted in order to determine whether the scores of emotional intelligence scores of the students participating in the study showed a significant difference according to the department variable; Emotional intelligence levels differ according to the section $\left(X^{2}=20,027, p\right.$ $<0.05)$. According to this, the emotional intelligence levels of Pre-School Teacher students are higher than the students in other departments except for Science Education Department students.

\subsection{Comparing Problem Solving Skills and Emotional Intelligence Levels According To Grade Level Variable}

In the fourth research question, whether the problem solving skills and emotional intelligence change based on the grade level is investigated.

Table 6. Comparison of the Factors by the Grade Level

\begin{tabular}{llccccc}
\hline Factors & Grade level & $\mathbf{n}$ & $\overline{\mathbf{X}}$ & $\mathbf{S D}$ & $\mathbf{X}^{\mathbf{2}}$ & $\mathbf{p}$ \\
\hline Problem Solving & 1st grade & 295 & 497,46 & 3 & 6,04 & 0,094 \\
& 2nd grade & 257 & 492,51 & & & \\
& 3rd grade & 255 & 541,57 & & & \\
Emotional & 4th grade & 226 & 542,64 & & & \\
Intelligence & 1st grade & 295 & 517,72 & 3 & 4,562 & 0,207 \\
& 2nd grade & 257 & 485,88 & & & \\
& 3rd grade & 255 & 525,64 & & & \\
& 4th grade & 226 & 541,71 & & & \\
\hline
\end{tabular}

According to the results of the Kruskal-wallis H Test conducted in order to determine whether the problem solving skill scores of the students participating in the study showed a significant difference according to the class level variable; problem-solving skills do not differ according to age $\left(\mathrm{X}^{2}=6,04, \mathrm{p}>0,05\right)$ (Table 6). According to the results of the Kruskal-wallis H Test conducted to determine whether the scores of emotional intelligence scores of the students participating in the study showed a significant difference according to the class level variable; Emotional intelligence levels do not differ according to class level $\left(\mathrm{X}^{2}=4,562, \mathrm{p}>0,05\right)$ (Table 6$)$.

\section{Discussion and Conclusion}

In this section, the findings of teacher candidates' emotional intelligence levels and problem solving skills are discussed. In this study, it was observed that teacher candidates' problem solving skills did not differ significantly in terms of gender. There are also studies that do not support these results as well as supporting studies. Hatay Polat and Tümkaya (2010) found that problem solving skills differed significantly in favor of female students. Heppner and Petersen (1982) found that men are more aware of problem-solving processes than women as a result of their study of personal differences related to problem solving skills. Bulut, Serin and Derin (2008), Cenkseven and Akar Vural (2006) observed that in their studies, the problem-solving skill according to gender differs in favor of women. Similarly, Ülger (2003), Güler (2006), Tümkaya and İflazoğlu (2000), Başar (2011), Elkin and Karadağli (2015), Özkütük et al. (2003), Bagcuci and Kinay (2013), Saracaloglu, Yenice and Karasakaloglu (2009) showed that the problem solving skills according to gender did not differ in their studies. The majority of studies examining whether the problem solving skills differ according to gender variable did not find any difference. In addition to this, it is necessary to carry out meta-analysis studies in order to examine the change of problem-solving skills in terms of gender, given that there are studies in favor of female students or in favor of male students.

No significant difference was found between gender and emotional intelligence. In the study conducted in favor of women in terms of gender interpersonal skills of prospective teachers; In terms of coping with stress, it was observed that there was a significant difference in favor of men. In general scoring, although the emotional intelligence levels of 
women were higher than the emotional intelligence level of men, this difference was not significant. Doğan (2009) found that the level of emotional intelligence only showed a significant difference in favor of males in the dimension of stress management. In 2008, Noland's study showed that the scores of men were higher than women's scores in stress management factor. According to these results, male students cannot be considered as despair, who do not lose their control, can cope with stress, are cold-blooded, and work better under pressure. This difference can be caused by personal or sexual identity and environmental factors, ie peer group factors (Doğan, 2009). Pilis and Özbaş (2014) emphasized that emotional intelligence does not differ according to gender, and that both gender and emotional intelligence levels are generally similar. Ekici and Titrek (2011), Güler (2006), Tunca (2010), Delikoyun (2017), Babaoğlan (2010), Deniz and Yılmaz (2005) are the studies that are parallel to the study. Durdu and Şahin (2017) found that emotional intelligence differed significantly in favor of women according to gender variable. According to researchers, women's emotional intelligence levels are often higher than men's emotional intelligence levels. According to the researchers, women are more successful than men in reading emotions. İkiz and Görmez (2010), Erdoğdu 2008), Bender (2006), Göçet (2006), Taşlıyan, Mum and Harbalıŏlu (2014), Üzel and Hangül (2011), Özmen (2008), Mayer, Caruso, and Salovey (1999) observed significant differences in favor of women in their studies.

When the studies investigating whether the level of emotional intelligence differ according to the gender variable, the majority of the studies have found a difference especially in favor of women. If we look at the way in which women and men grow up in our society, we can observe that women cannot and cannot fully experience certain emotions. In this study, although the difference between women and men is higher, it can be caused by variable group. A significant difference was found between age variable and problem solving skills. It was observed that the students' problem solving skills differed significantly in terms of age. Accordingly, the problem solving skills of 17-20 year old students are lower than the other age groups. In addition, a statistically significant difference was found in favor of the students over the age of 29 in comparing the problem solving skills of students aged between 29 and 21-24. Pakaslahti et al. (2002) found that the younger age group used problem solving skills more effectively (Yildırım et al., 2011). Korkut (2002) found that problem solving skills were significantly different in favor of the younger group. Yerli (2009) found that problem solving skills on different age groups did not differ significantly, and that managers of different ages perceived problem-solving skills on an equal level. Özkütük et al. (2003), Basar (2011), Elkin and Karadagli (2015), Yilmaz et al. When the studies examining the differentiation of the problem solving skills according to the age variable, it is observed that there are studies in favor of both the younger group and the older age group, but most of the studies show that the problem-solving skills according to age do not differ.

A significant difference was found between age variable and emotional intelligence level. Emotional intelligence levels of the students differed significantly in terms of age. Multi Health System Inc. In a study conducted on 3830 people in America, it has been emphasized that as people age, emotional intelligence increases and cognitive intelligence decreases as they age (Tunca, 2010). Özmen (2008) found differences in emotion management, emotion motivation, empathy, social skills sub-factors and total emotional intelligence scores. According to this difference, as the age increases, the level of emotional intelligence is increasing. Similarly, Güler (2006), Tunca (2010), Sevindik, Uncu and Dağ (2012), Kızll (2014) are the other studies in which the difference is observed. Yilmaz and Sahin (2001)'s studies showed that emotional intelligence did not differ according to age. Similarly, the studies conducted by Yerli (2009), Karaca (2014), Delikoyun (2017), and Özcan (2012) are the studies in which no significant differentiation was observed in the levels of emotional intelligence in terms of age. Stein and Book (2003), teachers, counselors, health experts, as a result of their work on people from various branches, using all proven methods of cognitive and behavioral therapy and psycho-dynamic theory by showing that the degree of emotional intelligence can be increased by supporting. As a result, when individuals are educated by scientific techniques, emotional intelligence levels increase (Güler, 2006).

The number of studies with differentiation has been found more frequently in studies investigating whether the level of emotional intelligence varies according to the age variable. According to the results of the research, the level of emotional intelligence increases with the experience gained as the age progresses. Scientists have stated that $50 \%$ of their emotional intelligence skills are learnable even if they are born, that everyone can learn emotional skills regardless of their innate abilities (Güler, 2006). It was observed that the problem solving skills of the students differed significantly in terms of the department. It was found out that the problem solving skills of Pre-School Teaching students were higher than the other departments except Science Education. Genç and Kalafat (2007) found that problem solving skills differed significantly according to the department variable. It was observed that the pre-service teachers in the Department of Primary School Education differed significantly from the pre-service teachers in Turkish, Science and English Language Teaching departments. This difference may arise from the elective and compulsory courses in the program, the development of problem-solving skills of some courses. Because the education of 
individuals can make the problem solving processes easier and more effective. Demirtaş and Dönmez (2008) observed that problem solving skills did not differ significantly according to the department variable. Similarly, Özkütük et al. (2003), Bağçeci and Kınay (2013), Elkin and Karadağ (2015) observed that their problem solving skills did not differ significantly according to the department. According to the studies examining the differentiation of problem solving skills according to the department variable, the majority of the studies did not differ according to the department. In this study, the difference in favor of pre-school teaching may be due to the elective and compulsory courses in this section, the development of problem-solving skills of the content of these courses or the more conscious selection of the teacher candidates.

A significant difference was found between the department variable and the emotional intelligence level. In the study, it was observed that the emotional intelligence levels of the students differed significantly in terms of the department. It has been observed that the level of emotional intelligence of pre-school teacher students is higher than other departments except Science Education. Göçet (2006) found in his study that Turkish Language Teaching, Social Studies Education, and Classroom Teaching students showed significant differences with respect to digital weighted sections. Kiz1l (2014) observed in his study that the level of emotional intelligence of Classroom Teachers is higher than the level of emotional intelligence of Science and Mathematical Science Teachers. Özmen (2008) stated that the level of emotional intelligence of Class Teachers is generally higher than other teachers. Therefore, it is possible for Class Teachers to communicate more closely with the student and his / her family and to get to know the student more closely. Again, Kırımoğlu, Yeniad and Çoban (2014), Erdoğdu (2008) found that emotional intelligence levels differ significantly according to the section. Özdemir (2015) found that students' emotional intelligence levels did not differ significantly according to departments. Kaynak (2013), Gürol (2008)'s studies in the level of emotional intelligence levels did not differ significantly according to the department. When we look at the studies examining whether the level of emotional intelligence differs according to the department variable, the majority of them have found a difference.

Considering the studies on the differentiation between the sections, there are studies in which there are differentiations especially in favor of verbal-weighted sections. It is a very important issue for the people to progress in the field of education to take into consideration their abilities while choosing the department and to educate the qualified people. However, the absence of differences between departments may be due to similar content or high levels of emotional intelligence among prospective teachers (Özdemir, 2015). In our study, the difference in favor of pre-school teacher candidates may have resulted from the fact that pre-service teachers chose more informed choices. There was no significant difference between grade level variable and problem solving skills. It was observed that the students' problem solving skills did not differ significantly in terms of grade level. Elkin and Karadağli (2015), Başar (2011), Akın et al., (2007), Tezel et al. (2009), Yılmaz et al. (2009) found similar results to the study. Genç and Kalafat (2007) found a significant difference in favor of 3rd grade pre-service teachers in their study. Tümkaya and İflazoğlu (2000) found that problem solving skills differed significantly in favor of grade 4 according to grade level variable in their study on classroom teaching students. Hatay Polat and Tümkaya (2010) found that problem solving skills differed significantly in favor of grade 4 according to grade level variable in the study they conducted on their class teacher candidates. The majority of the studies examining whether the problem solving skills differ according to the grade level variable have not been found to differ as in this study. When we look at the studies that differ according to the grade level, this difference can be explained to the students who are new to the university; problems in academic, social, personal, emotional and relations with the opposite sex can be shown. In the new life sphere, students can face many problems and this requires students to take responsibility for their lives in a short period of time. As senior students now go beyond the adaptation problem, the results in their favor may be meaningful.

No significant difference was found between the level of the class level and the emotional intelligence level. It was observed that the level of students' emotional intelligence did not differ significantly in terms of grade level. Üzel and Hangül (2011) found that the level of emotional intelligence did not differ significantly according to grade level. Sevindik, Uncu and Dag (2012)'s study in a similar way is not found in the study. Özdemir (2015), Kaynak (2013), Deniz and Yilmaz (2005)'s studies are similar studies in which the levels of emotional intelligence differ significantly according to class level. According to the studies examining the difference of the level of emotional intelligence according to the class level variable, it was found that the majority of the studies were different. However, there are studies in which there is no difference as in our study. When the literature is examined, it can be said that the emotional intelligence level is generally high due to the fact that the level of emotional intelligence is expected to show development and change from first to fourth year due to the development of emotional intelligence level. 


\section{Recommendations for Further Researchers}

In order to train teachers with high levels of emotional intelligence and problem-solving skills, pre-service teachers should pay attention to the quality of the departments and the emotional characteristics they bring. In this study, sub-factors of emotional intelligence were examined according to gender. The change of emotional intelligence with different factors should be examined in follow up studies.

\section{Acknowledgements}

This study was completed as a Master Thesis at the Zonguldak Bülent Ecevit University, Turkey under the guidance of Dr. Elif Akdemir.

\section{References}

Acar, F. T. (2001). The relationship between emotional intelligence skills and task-oriented leadership behavior: A field study on bank branch managers/Duygusal zeka yeteneklerinin göreve yönelik ve insana yönelik liderlik davranışları ile ilişkisi: Banka şube müdürleri üzerine bir alan araştırması. Unpublished $\mathrm{PhD}$ Thesis, İstanbul University Institute of Social Sciences, İstanbul.

Akın S., Güngör İ., Mendi B., Şahin N., Bizat E., \& Durna Z. (2007). Nursing Student's Problem Solving Skills and Internal-External Locus of Control. Journal of Education and Research in Nursing, 4(2), 30-36.

Akpınar, Ş. (2014). The Investıgatıon Of The Problem Solving And Social Skills Of Teacher Candidates. Unpublished Master Thesis. Kahramanmaraş Sütçü İmam University, Kahramanmaraş.

Arkan, K. (2011). Sinıf ögretmenlerinin problem çözme becerisini kazandırmaya yönelik öz-yeterlikleri ile ilkögretim ögrencilerinin problem çözme becerileri arasındaki ilişki. Unpublished Master Thesis, Marmara University Education Sciences Institute.

Babaoğlan, E. (2010). Emotional Intelligence in School Administrators. Ahi Evran University Education Faculty Journal, 11(1), 119-136.

Bağçeci, B., \& Kınay, İ. (2013). Investigation of Teachers' Problem Solving Skills According To Some Variables, Electronic Journal of Social Sciences, 12(44), 335-347.

Bar-On, R. (1997, August). Development of the Bar-On EQ-i: A measure of emotional and social intelligence. In 105th Annual Convention of the American Psychological Association in Chicago.

Bar-On, R. (2005). The impact of emotional intelligence on subjective well-being: Research article: general. Perspectives in Education, 23(1), 41-62.

Bar-On, R. (2006). The Bar-On model of emotional-social intelligence (ESI). Psicothema, 18.

Başar, G., Semiha, A., \& Durna, Z. (2015). Hemşirelerde ve hemşirelik öğrencilerinde problem çözme ve iletişim becerilerinin değerlendirilmesi. Gümüşhane University Health Sciences Institute Journal, 4(1), 125-147.

Bender, M. T. (2006). Resim-iş eğitimi öğrencilerinde duygusal zekâ ve yaratıcılık ilişskileri (Unpublished Doctoral Dissertation), DEÜ Education Sciences Institute, İzmir Turkey

Cenkseven, F., \& Akar Vural, R. (2006). Comparing Adolescents Perceived Problem Solving Skills According To Need For Cognition And Genders. Eurasian Journal of Educational Research, 25, 45-53.

Cingisiz, N., \& Murat, M. (2010). Investigation the Levels of Emotional Intelligence of the Couples Making Decision for Marriage, Gaziantep University Social Sciences Journal, 9(1), 99-114.

Creswell, J. W. (2002). Educational research: Planning, conducting, and evaluating quantitative (pp. 146-166). Upper Saddle River, NJ: Prentice Hall.

Delikoyun, D. (2017). Üniversite Öğrencilerinde Duygusal Zekâ ve Benlik Saygısı Arasındaki İlişki. Unpublished Thesis, Hasan Kalyoncu University, Social Sciences Institute.

Demirtaş, H., \& Dönmez, B. (2008). Secondary School Teachers' Perceptions about Their Problem Solving Abilities, İnönü University. Journal of the Faculty of Education, 9(16), 177-198.

Deniz, M. E., \& Y1lmaz, E. (2016). An Investigation Of The Relationship Between Emotional Intelligence And Coping With Stress Styles Of The University Students. Türk Psikolojik Danışma ve Rehberlik Dergisi, 3(25).

Doğan, U. (2009). Lise Öğrencilerinin Duygusal Zekâ Düzeyleri ile Problem Çözme Becerilerinin Bazı Değişkenlere 
Göre Incelenmesi. Unpublished Master Thesis, Muğla University, Social Sciences Institute, Muğla.

Durdu, İ., \& Şahin, S. (2017). Examining Teachers' Emotional Intelligence Related To Some Variables (A Case Of İzmir City Buca District), Dokuz Eylül University, Anatolian Journal of Educational Leadership and Instruction, 5(1), 44-58.

Ekici, Ö. O., \& Titrek, O. (2011). Perceptions Of Principals And Teachers Concerning The Achieved Level Of Organizational Intelligence Within Primary Schools. Hacettepe University Journal of Education, 40, $152-163$.

Elkin, N., \& Karadağlı F. (2015). Evaluation of University Students Problem Solving Skills. Adıyaman University, Health Science Journal, 1(1), 11-18.

Erdoğdu, M. (2008). Research On Emotional Quotıent In Terms Of Certain Variables. Electronic Journal of Social Sciences, 7(23), 62-76.

Genç, S. Z., \& Kalafat, T. (2007). The Research On Evaluatıon Of Prospective Teachers' Democratic Attıtudes And Problem Solving Skills According As Different Variables. Pamukkale University Education Faculty Journal, 22(22), 10-22.

Germi, H., \& Sunay, H. (2007). Evaluation of The Problem Solving Skills of The Sport Managers Working At General Directorate for Youth And Sport. Gazi Journal of Physical Education and Sport Sciences, 43.

Göçet, E. (2006). Üniversite ögrencilerinin duygusal zekâ düzeyleri ile stresle basa çikma tutumlari arasindaki iliski. Unpublished Master Thesis, Sakarya University, Social Sciences Institute, Sakarya.

Güçlü, N. (2003). Lise müdürlerinin problem çözme becerileri. Milli Eğitim Journal, 160(1).

Güler, A. (2006). The Research Of The Relation Between The Emotional Intelligence And Problem Solving Skills Of Primary School Teachers. Unpublished Master Thesis, Yeditepe University Social Sciences Institute, İzmir.

Gürol, Ö. (2008). The Relatıon between Level of Emotıonal Intelligence of Teachers in Elemantary Schools and Their Talents Of Dealing With Stress. Unpublished Master Thesis. Yeditepe University Social Sciences Institute, İstanbul.

Hatay Polat, R., \& Tümkaya, S. (2010). An Investigation of the Students of Primary School Problem Solving Abilities Depending on Need for Cognition. Elementary Education Online, 9(1), 346-360.

Heppner, P. P., \& Petersen, C. H. (1982). The development and implications of a personal problem-solving inventory. Journal of counseling psychology, 29(1), 66. https://doi.org/10.1037/0022-0167.29.1.66

Karaca, P. (2014). The Relationship Between Teacher's Emotional Intelligence Levels With Conflict Management Strategies Used By Teachers. Unpublished Master Thesis, Zirve University, Institute of Social Sciences, Gaziantep.

Kaynak, A. (2013). Examining The Relationship between the Level of Emotional Intelligence And The level Of aggression In Terms Of Some Variables among The Faculty Of Education students. Gaziantep University, Education Sciences Institute, Gaziantep.

Kırımoğlu, H., Yeniad, S., \& Çoban, E. (2014). Evaluation of Emotional Intelligence Levels of Candidate Teachers In Terms Of Status of Playing Sports (Mustafa Kemal University Sample). Gaziantep University Journal of Social Sciences, 13(1), 201-209. https://doi.org/10.21547/jss.256843

Korkut, F. (2002). Problem Solving Skills of High School Students. Hacettepe University Education Faculty Journal, $22,177-184$.

Mayer, J. D., \& Salovey, P. (1990). Emotional Intelligence. Baywood Pub1ishlnl Co., Inc. $185-212$. https://doi.org/10.2190/DUGG-P24E-52WK-6CDG

Mayer, J. D., \& Salovey, P. (1993). The Intelligence of Emotional Intelligence. Intelligence, 17, $433-442$. https://doi.org/10.1016/0160-2896(93)90010-3

Mayer, J. D., Caruso, D. R., \& Salovey, P. (1999). Emotional intelligence meets traditional standards for an intelligence. Intelligence, 27(4), 267-298. https://doi.org/10.1016/S0160-2896(99)00016-1

Özcan, H. (2012). Empathic Disposition And Empathic Skills Of Nurses: Example Gümüşhane, Example. University Journal Of Health Sciences, 1(2), 60-68.

Özdemir, M. (2015). A Survey On Emotional Intelligence And Life Satisfaction Level Of Education Faculty Students. Unpublished Doctoral Dissertation. 
Özkütük, N., Silkü, H. A., Orgun, F., \& Yalçınkaya, M. (2003). The Problem Solving Skills of Teacher Candidates. Ege Education Journal, 3(2).

Özmen, Z. K. (2008). İlköğretim Öğretmenlerinin Duygusal Zekâ Düzeyleri. İstanbul Sabahattin Zaim University Journal, 2(1).

Pakaslahti, L., Karjalainen, A., \& Järviven, L. K. (2002). Relationships between adolescent prosocial problem solving strategies, prosocial behavior, and social acceptance. International Journal of Behavioral Development, 26(2), 137-144. https://doi.org/10.1080/01650250042000681

Pilis, A., \& Özbaş, S. (2014). According to Perceptions Evaluation of Emotional Intelligence Skills of School Administrators. Near East University Social Sciences Institute Journal, 2(2).

Serin, N. B., \& Derin, R. (2008). The Factors Affecting Primary School Students' Perceptions Of İnterpersonal Problem Solving Skills And The Levels Of Locus Of Control. International Human Sciences Journal, 5(1), 1-18.

Sevindik, F., Uncu, F., \& Dag, D. G. (2012). The investigation of emotional intelligence in health school students to some variables. FÜ Săg. Bil. Tip Derg, 26(1), 21-26.

Taşlıyan, M., Hırlak, B., \& Harbalığlu, M. (2014). The Relationship Between Emotional Intelligence, Communication Skills And Academic Achievement: An Application On University Students. ASSAM International Refereed Journal, 2(3), 45-58.

Tezel, A., Arslan S., Topal M., Aydoğan Ö., Koç Ç., \& Şenlik M. (2009). The Investigation of The Problem Solving Skill and Depression Level of Nursing Student. Atatürk Üniversitesi Hemşirelik Yüksekokulu Dergisi, 12(4), 1-4.

Titrek, O. (2013). IQ'dan EQ'ya: Duyguları Zekice Yönetme, Geliştirilmiş 4. Baskı, Ankara: Pegem Akademi.

Tümkaya, S., \& İflazoğlu, A. (2000). An Investigation Of Automatıc Thought And Problem Solvıng Levels Of Students In Classroom Teaching Unıt Of Çukurova University According To Some Socio-Demographic Variables. Social Sciences Journal, 6(6), 143-158.

Tunca, Ö. (2010). Effects Of Emotional Intelligence Level On Class Management Skills And A Research. Unpublished Master Thesis, İstanbul University, İstanbul.

Ülger, Ö. E. (2003). The Relationship Between Leadership Behaviours and Problem Solving Abilities. Unpublished Master Thesis, Beykent University, İstanbul.

Üzel, D., \& Hangül, T. (2012). Duygusal zekâ ve akademik başarı arasındaki ilişski. Ulusal Fen Bilimleri ve Matematik Eğitimi Kongresi, Niğde.

Yerli, S. (2009). Illk ve Orta Öğretim Okullarındaki Yöneticilerin Duygusal Zekâ ve Problem Çözme Becerileri Arasindaki Illişki. Unpublished Master Thesis. İstanbul Maltepe University, İstanbul.

Yıldırım, A., Hacıhasanoğlu, R., Karakurt, P., \& Türkleş, S. (2011). Problem solving skills and influential factors in high school students. International Human Sciences Journal, 8(1), 905-921.

Yılmaz, E., Karaca, F., \& Yılmaz, E. (2009). Examining the Problem Solving Skills and Some Related Factors of the Health College Students, Atatürk University Hemşirelik Yüksekokulu Dergisi, 12(1), 38-48.

Yılmaz, M. (2015). Nephrology Nursing and Emotional Intelligence. Nefroloji Hemşireliği Journal, 2, 13-18.

Zahed-Babelan, A., \& Moenikia, M. (2010). The role of emotional intelligence in predicting students' academic achievement in distance education system. Procedia-Social and Behavioral Sciences, 2(2), 1158-1163. https://doi.org/10.1016/j.sbspro.2010.03.164 